\title{
Occupational Allergic Contact Dermatitis in Tunisia: Epidemiology and Occupational Outcome
}

\author{
Asma Aloui, Maher Maoua*, Houda Kalboussi, Imène Kacem, Sana El Guedri, Aicha Brahem, \\ Olfa El Maalel, Faten Debbabi, Souhaiel Chatti, Néjib Mrizak
}

Department of Occupational Medicine, Faculty of Medicine of Sousse, University of Sousse, Farhat Hached

Teaching Hospital, Sousse, Tunisia

Email: *maouamaher@yahoo.fr

How to cite this paper: Aloui, A., Maoua, M., Kalboussi, H., Kacem, I., El Guedri, S., Brahem, A., El Maalel, O., Debbabi, F., Chatti, S. and Mrizak, N. (2018) Occupational Allergic Contact Dermatitis in Tunisia: Epidemiology and Occupational Outcome. Occupational Diseases and Environmental Medicine, 6, 107-117. https://doi.org/10.4236/odem.2018.63009

Received: June 8, 2018

Accepted: August 13, 2018

Published: August 16, 2018

Copyright $\odot 2018$ by authors and Scientific Research Publishing Inc. This work is licensed under the Creative Commons Attribution International License (CC BY 4.0).

http://creativecommons.org/licenses/by/4.0/ (c) (i) Open Access

\begin{abstract}
Background: Occupational allergic contact dermatitis (ACD) is one of the most frequent diseases on the workplace worldwide. Its national incidence and prevalence were not previously studied in Tunisia. Objective: To assess incidence of occupational allergic contact dermatitis and its occupational outcome in Tunisia. Methods: Descriptive epidemiological study of all cases of occupational allergic contact dermatitis reported from 2002 to $2012 \mathrm{in} \mathrm{Tu}$ nisia and recognized by the medical commissions of the National Health Insurance Fund. Results: 315 cases of occupational ACD were collected representing an annual incidence of 31.65 cases $/ 100.000$ workers in the private sector in Tunisia. The mean age of our population was $42.70 \pm 9.02$ years with a male predominance (sex ratio 3.03). The most affected sectors were the clothing sector (14.3\% of cases) and the cement industry (13.7\% of cases). Patch tests were positive in 188 patients (59.67\%). The most frequently positive allergen was potassium dichromate in $27.3 \%$ of the cases. Overall, $25.4 \%$ of patients had lost their jobs. After multiple binary logistic regression, job loss had a statistically significant relationship with localization of lesions on the face and on dominant hand. Conclusion: Occupational ACD is frequent in Tunisia and is responsible for an important rate of job loss. Preventive measures must be reinforced, especially the wearing of protective gloves.
\end{abstract}

\section{Keywords}

Epidemiology, Occupational Disease, Allergic Contact Dermatitis, Job Loss, Tunisia 


\section{Introduction}

Occupational dermatitis is one of the leading causes of occupational diseases in several countries. They still occupy an advanced position in the list of compensable diseases throughout the world. In the United States, occupational skin diseases account for $34 \%$ of occupational diseases [1]. In Tunisia, according to the latest statistics of the National Health Insurance Fund, they still remain 4th among the compensable occupational diseases [2].

The most reported pathological form in industrialized countries is allergic contact dermatitis (ACD) [3] which is the clinical expression of a type IV hypersensitivity (delayed-type hypersensitivity) [4].

The socio-economic implications of these diseases are significant with possible impact on the pursuit of professional activity and the quality of liafe [5]. Several epidemiological studies have shown that $\mathrm{ACD}$ is a significant risk factor for absenteeism, loss of employment and daily impairment [6] [7].

The epidemiological analysis of occupational allergic contact dermatitis is necessary in order to discern their etiologies, their risk factors and their consequences. As a result, targeted and adequate preventive measures can be developed and implemented. In Tunisia, studies carried out on this subject are limited to a sector of activity, a specific exposure or a particular region. No survey had yet analyzed the epidemiological characteristics of occupational ACD at the national level.

Thus, we carried out an epidemiological study on all the cases of Occupational ACD recognized by the committees of the National Health Insurance Fund covering the entire Tunisian territory during the period from 2002 until 2012 in the perspectives of determining the prevalence and incidence of occupational ACD in Tunisia and analyzing the socio-professional and medical characteristics of patients with allergic contact dermatitis.

\section{Methods}

We conducted a descriptive epidemiological study covering all subjects with occupational allergic contact dermatitis reported in the private sector in Tunisia from 2002 to 2012 and recognized by the competent medical commissions of the National Health Insurance Fund (CNAM). Thus, our cases were the social insured presenting an occupational allergic contact dermatitis recognized by these committees on the basis of several medical, technical and administrative conditions.

In Tunisia, the recognition of the occupational origin of contact dermatitis is based on the law 94 - 28 published in the Official Journal of the Tunisian Republic in 21 February 1994. Occupational diseases are listed in tables (84 tables) corresponding to occupational risk factors. Legal recognition requires compliance with several conditions: the disease is listed in one of the 84 tables, ACD is confirmed by patch tests or by occupational rhythmicity (improvement of lesions during periods of eviction and recurrence of lesions after return to work), 
respect of the legal delay between last exposition to the occupational etiological factor and the onset of the disease, and exercised work habitually exposes to the occupational risk factor. Thus, several cases can be reported as occupational DCAs without positive patch tests, on the basis of occupational rhythmicity of the disease.

\subsection{Data Collection}

Data collection was carried out using a pre-established questionnaire. Sources of data were medical documents (the initial medical certificate, the results of the patch tests), and administrative documents (a sheet of declaration of occupational disease, certificates of work, medical Investigation, the results of expert opinions, a request for a pension) constituting the files of the patients.

From these documents, the data collected concerned the identification of patients, the socio-professional characteristics (age, gender, origin, professional qualification, sector of activity, occupational seniority), medical examination results, patch test results, data from the technical survey including the actual exposure to the causal agent, rates of permanent partial disability and occupational outcome.

\subsection{Statistics Analysis}

Data were analyzed using SPSS 18.0 software. For the descriptive study, we calculated frequencies and percentages for the qualitative variables, as well as averages, standard deviations, medians and the extent of extreme values for quantitative variables. For the comparison of means, Student's " $t$ " test was used to compare two independent series and the Snedecor " $\mathrm{f}$ " test for parametric variance analysis (ANOVA) for the comparison of several means. Pearson's Chi square test was used for testing relationships between categorical variables.

For multivariate analysis, we used a multiple binary logistic regression with the "job loss" as a dependent variable. The inclusion of independent variables in the regression models was done when their degree of significance was less than 0.2. For all statistical tests, the threshold of significance $\mathrm{p}$ was set to 0.05 .

\section{Results}

A total of 315 cases of allergic contact dermatitis were collected representing a prevalence of $4 \%$ of all occupational diseases reported during the same period. The annual incidence was estimated at 31.65 cases $/ 100,000$ workers in the private sector in Tunisia. The majority of ACD cases were reported in 2003 with 45 cases (14.3\%) and in 2005 with 40 cases (12.7\%). Only 14 cases (4.4\%) were reported in 2011 as shown in Figure 1.

The mean age of our population was $42.70 \pm 9.02$ years. A male predominance was noted with 237 men $(75.2 \%)$ compared with only 78 women $(24.8 \%)$. The sex ratio was 3.03 . The majority of workers were employed in the clothing sector $(n=45$, i.e. $14.3 \%), 43$ cases $(13.7 \%)$ in the cement industry and 21 cases $(6.7 \%)$ 


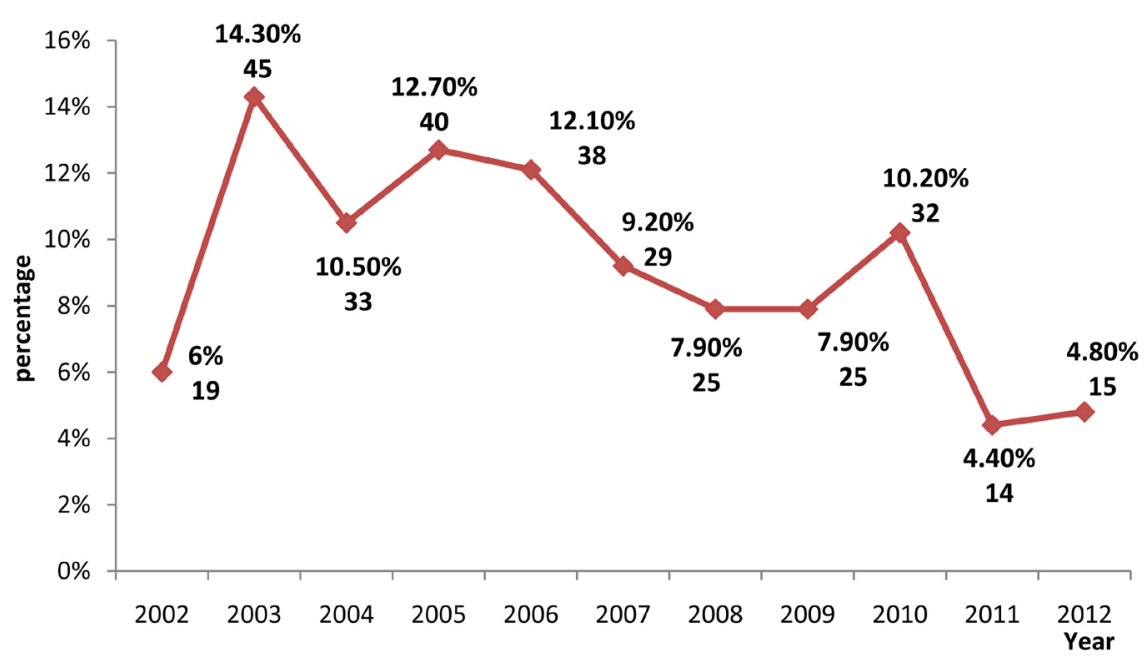

Figure 1. Annual distribution of occupational allergic contact dermatitis in Tunisia.

in the building materials sector. The average job tenure was $11.60 \pm 8.69$ years with extremes of 1 and 35 years. The hand was the most affected site in $87.6 \%$ of cases, followed by the forearm in 79 cases $(25.1 \%)$. Both hands were affected in 240 cases $(76.2 \%)$. Cement was the most incriminated product with 63 cases (20\%), followed by chromium (50 cases, 15.9\%), and glues (32 cases, 10.2\%). Almost all of the workers $(\mathrm{n}=312$, i.e. $99.04 \%)$ were patch tested using the European baseline series. These tests were positive in 188 patients $(59.67 \%)$. The most frequently found allergens were potassium dichromate in $27.3 \%(n=86)$, cobalt chloride in $18.7 \%(n=59)$, and nickel sulfate in $15,3 \%(n=48)$. The occupational relevance of Epoxy resin and Quaternium 15 were at 100\% (Table 1). In total, 126 positive allergens from the European patch test series were occupationally relevant (40\%).

Patch tests with the textile battery were performed in 20 patients (6.3\%). The most common allergens were Disperse Blue 124 in $1.6 \%$ of patients $(n=5)$, followed by 4 -Aminophenol in $1.3 \%$ of cases $(n=4)$ and Disperse Blue 3 in $1 \%$ of patients $(\mathrm{n}=3)$.

After recognition of the occupational origin of their disease, 171 cases of ACD (54.3\%) had permanent partial disability rates ranging from $0 \%$ to $40 \%$ with an average of $13.65 \% \pm 6.76 \%$.

Regarding the occupational outcome of these workers, the majority of cases (116 cases, 36.8\%) were reclassified, while $80(25.4 \%)$ had lost their jobs (Table 2).

Women with ACD were younger than men $(38.04 \pm 10.05$ years versus 44.23 \pm 8.11 years) with a lower occupational seniority $(9.8 \pm 6.58$ years versus $12,16 \pm$ 9.22 years). Women were more likely to develop facial dermatitis ( $O R=3.8,95 \%$ CI [2.04 - 7.16]), whereas in men, hands were the most affected parts $(\mathrm{OR}=2$, $43,95 \%$ CI [1.2 - 5]). Female workers had a greater risk of sensitization to nickel and dyes, whereas a risk of sensitization to chromium, cement and glues was greater in men. Among the allergens in the European baseline series, Quaternium 
Table 1. Results and occupational relevance of positive patch tests.

\begin{tabular}{|c|c|c|c|}
\hline Allergens & $\begin{array}{l}\text { Number } \\
\text { of cases }\end{array}$ & $(\%)$ & $\begin{array}{c}\text { Occupational } \\
\text { relevance of } \\
\text { positive allergens }\end{array}$ \\
\hline Potassium dichromate & 86 & 27.5 & $50(58.13 \%)$ \\
\hline Cobalt (II) chloride hexahydrate & 59 & 18.9 & $17(28.8 \%)$ \\
\hline Nickel sulfate & 48 & 15.3 & $22(45.8 \%)$ \\
\hline Thiuram mix & 25 & 8.0 & $1(4 \%)$ \\
\hline N-Isopropyl-N-phenyl-4-phenylenediamine (IPPD) & 16 & 5.1 & $2(12.5 \%)$ \\
\hline Formaldehyde & 12 & 3.8 & $7(58.3 \%)$ \\
\hline Paraben mix & 10 & 3.2 & 0 \\
\hline Epoxy resin & 10 & 3.2 & $10(100 \%)$ \\
\hline Colophonium & 9 & 2.8 & $3(33.3 \%)$ \\
\hline Peru balsam & 7 & 2.2 & $3(42.8 \%)$ \\
\hline P-Phenylenediamine (PPD) & 7 & 2.2 & $3(42.8 \%)$ \\
\hline Fragrance mix & 4 & 1.2 & $1(25 \%)$ \\
\hline 4-tert-Butylphenol-formaldehyde resin (PTBP-FR) & 4 & 1.2 & 0 \\
\hline 2-Mercaptobenzothiazole (MBT) & 4 & 1.2 & $1(25 \%)$ \\
\hline Quaternium 15 & 4 & 1.2 & $4(100 \%)$ \\
\hline Benzocaine & 3 & 0.9 & 0 \\
\hline Lanolin alcohol & 3 & 0,9 & 0 \\
\hline Mercapto mix & 3 & 0,9 & $1(33.3 \%)$ \\
\hline Hydroxymethylpentylcyclohexene-carboxaldehyde $5 \%$ & 3 & 0,9 & 0 \\
\hline Primin (2-Methoxy-6-n-pentyl-4-benzoquinone) & 2 & 0.6 & \\
\hline Sesquiterpene lactone mix $\mathrm{Mx}-18$ & 2 & 0.6 & $1(50 \%)$ \\
\hline Fragrance mix II & 1 & 0.3 & 0 \\
\hline Kathon CG & 1 & 0.3 & 0 \\
\hline Methyldibromo glutaronitrile $0.3 \%$ & 1 & 0.3 & 0 \\
\hline
\end{tabular}

Table 2. Occupational outcome among Tunisian patients with occupational ACD.

\begin{tabular}{ccc}
\hline Outcome & Number of cases & $(\%)$ \\
\hline Outplacement & 116 & 36.8 \\
Job loss & 80 & 25.4 \\
Same job & 65 & 20.6 \\
Decrease of financial income & 34 & 10.8 \\
Change of company & 16 & 5.1 \\
Change of workstation & 3 & 1 \\
Workstation management & 1 & 0.3 \\
Total & 315 & 100 \\
\hline
\end{tabular}


$15(\mathrm{p}=0.048, \mathrm{OR}=9.44,95 \%$ CI $[0.96-92])$ nickel sulphate $\left(\mathrm{p}<10^{-3}, \mathrm{OR}=\right.$ 3.18; 95\% CI $[1.68-6.04])$ and para-phenylenediamine $(\mathrm{p}=0.011, \mathrm{OR}=8.04$, $95 \%$ CI [1.52 - 42.3]) were sensitizers significantly related to women.

Only two variables were significantly related to job loss. Employees aged more than 44 years and those working in the construction sector had a higher average PPI with $\mathrm{p}=0.039$ and $\mathrm{p}=0.038$ respectively.

After multiple binary logistic regression, facial ACD and ACD of the dominant hand were the variables associated with a greater risk of job loss. Indeed, ACD of the predominant hand was associated with a 14 -fold greater risk of job loss $\left(\mathrm{p}<10^{-3}, \mathrm{OR}=14.02,95 \% \mathrm{CI}[6.88-28.57]\right)$ and the risk of job loss was 2.8 times greater among patients with facial ACD $(\mathrm{p}=0.01, \mathrm{OR}=2.83,95 \% \mathrm{CI}[1.27$ - 6.26]) (Table 3).

\section{Discussion}

Prevalence and incidence of ACD vary from a country to another. The prevalence of ACD decreased from $1.05 \%$ in 2003 to $0.77 \%$ in 2007 according to CNAMT

Table 3. Multiple binary logistic regression: job loss and interest variables.

\begin{tabular}{|c|c|c|c|c|c|c|c|c|}
\hline \multicolumn{5}{|c|}{ First Step } & \multicolumn{4}{|c|}{ Final Step } \\
\hline \multirow[b]{2}{*}{ Variables } & \multirow[b]{2}{*}{$\mathrm{p}$} & \multirow[b]{2}{*}{ OR } & \multicolumn{2}{|c|}{ IC $95 \%$} & \multirow[b]{2}{*}{$\mathrm{p}$} & \multirow[b]{2}{*}{ OR } & \multicolumn{2}{|c|}{ IC 95\% } \\
\hline & & & $\begin{array}{c}\text { Inf } \\
\text { borne }\end{array}$ & $\begin{array}{l}\text { Sup } \\
\text { borne }\end{array}$ & & & $\begin{array}{c}\text { Inf } \\
\text { borne }\end{array}$ & $\begin{array}{c}\text { Sup } \\
\text { borne }\end{array}$ \\
\hline Gender & 0.25 & 0.59 & 0.24 & 1.45 & & & & \\
\hline Median age ( 44 years) & 0.49 & 0.77 & 0.37 & 1.60 & & & & \\
\hline No professional qualification & 0.67 & 0.85 & 0.41 & 1.75 & & & & \\
\hline Median of seniority ( 10 years) & 0.75 & 1.12 & 0.54 & 2.29 & & & & \\
\hline Personnel antecedents of asthma & 0.72 & 1.29 & 0.30 & 5.47 & & & & \\
\hline Personnel antecedents of rhinitis & 0.42 & 0.24 & 0.008 & 7.65 & & & & \\
\hline Location on the face & 0.02 & 2.85 & 1.16 & 7.00 & 0.01 & 2.83 & 1.27 & 6.26 \\
\hline Location on the hands & 0.48 & 0.64 & 0.18 & 2.24 & & & & \\
\hline Location in the forearms & 0.64 & 0.82 & 0.37 & 1.83 & & & & \\
\hline Location on foot & 0.92 & 1.04 & 0.45 & 2.42 & & & & \\
\hline Lesion of dominant hand & $10^{-3}$ & 14.62 & 7.04 & 35.37 & $10^{-3}$ & 14.02 & 6.88 & 28.57 \\
\hline Lesion of both hands & 0.006 & 0.29 & 0.12 & 0.70 & $10^{-3}$ & 4.16 & 2 & 9.09 \\
\hline Positive patch-test & 0.48 & 1.39 & 0.54 & 3.55 & & & & \\
\hline $\begin{array}{c}\text { Sensitization to } \\
\text { Potassium dichromate }\end{array}$ & 0.44 & 1.39 & 0.59 & 3.26 & & & & \\
\hline Sensitization to cobalt & 0.92 & 1.04 & 0.40 & 2.66 & & & & \\
\hline Sensitization to nickel & 0.71 & 1.20 & 0.45 & 3.16 & & & & \\
\hline Cement industry & 0.22 & 0.41 & 0.10 & 1.70 & & & & \\
\hline Building materials sector & 0.37 & 0.30 & 0.02 & 4.16 & & & & \\
\hline Textile and clothing sector & 0.96 & 1.02 & 0.42 & 2.47 & & & & \\
\hline
\end{tabular}


statistics in France [8]. In the United Kingdom, dermatologists reported, between 1993 and 2004, 22,284 cases of occupational ACD, representing a prevalence of $77 \%$ of all occupational dermatoses [9]. Similarly, ACD accounted for $94 \%$ to $98 \%$ of occupational dermatoses reported in Denmark [10] and $21.3 \%$ in Spain, mainly in the hairdressing and catering sectors [11].

In our study, the annual cumulative incidence of occupational allergic contact dermatitis was estimated at 31.65 cases/100,000 workers in the private sector in Tunisia. The annual incidence of contact dermatitis in most countries ranged from 5.7 to 101 cases per 100,000 employees/year. The most reliable studies estimate it between 11 and 86 cases per 100000 employees/year [12] [13]. Indeed, Ahn Y-S et al. [14] estimated this incidence to be 78 cases per 100,000 workers in the United Kingdom, while in Singapore in 2007, Gan W-H et al. [15] found an annual incidence of occupational contact dermatitis of 400/100,000 conscripts/year. However, other studies have found lower incidences, such as Schwensen J. et al. [16] in their study conducted in Denmark on all cases of occupational dermatoses diagnosed between September 2003 and December 2010, which found an average annual incidence of occupational dermatoses estimated at 19 cases per 100,000 workers. This variability can be explained by several factors. According to Kopferschmitt-Kubler MC [17], this may be an underreporting of the link between the disease and the exposure at work related to either the patient or the physician. The number of cases may also depend on the type of industries in a given geographical area, the age and gender of patients, the variability of data collection systems, and the type of occupational diseases' reporting system (by patients or by doctors).

During recent years, the incidence of reporting occupational contact dermatitis fell in Tunisia, which could be explained by several factors. First, even if technical and legal preventive actions were intensified during the last two decades, the main threat for workers is the growing job insecurity due to the fragility of their contracts. In Tunisia, workers become incumbent employees after 4 years of occupational activity. During this period, they still contract workers and are concerned with the risk of losing the opportunity of appointment to a permanent post if they declare an occupational disease. Second, the type of industries is gradually changing toward "cleaner" activities such as electronics and textile sectors in addition to the mechanization and automating of several work stations, reducing by the fact direct contact with allergens.

Textile and clothing sector is considered strategic for the Tunisian national economy. It is the main sector of the manufacturing industry in terms of exports and employment [18], which explains that most patients with ACD were workers in this sector. The textile and clothing sector is composed of different activities such as spinning, tanning and confection. In Tunisia, the most developed activities are spinning and confection with fewer exposed workers to dyes. The majority of ACD cases in the textile sector are secondary to manipulation of metallic tools that drop nickel, chromium and cobalt such as scissors and thimbles. The localization of lesions in the index and thumb is usually concordant. 
Cashman MW et al. [1] had identified the most affected sectors by ACD in USA which were hairdressing, building and public works, and metallurgy. Whereas in Spain [11], the most affected sectors were construction, hairdressing, metallurgy and food industry.

Table 4 resumes the most common etiologic factors in several countries. While metals such as potassium dichromate and nickel sulfate are frequently identified as causal allergens, differences in top three allergens might be associated to differences between type of industries and occupations in each country.

As the main working tool, hands are often brought into contact with various aggressive agents, mostly from the professional environment. Our results are similar to those found in other studies concerning the location of lesions. Raison-Peyron N. [19] found that the involvement of hands and forearms was predominant and was observed in more than $80 \%$ of the cases.

Another more rare location is the face [12], in particular the eyelids by airborne mechanism (volatile products) or due to contact with contaminated hands or gloves.

In our study, facial dermatitis was noted in $16.2 \%$ of cases and was predominant in women. Female hands would be more in contact with the face and would therefore be more often responsible for facial dermatitis [20]. This location is affected in $10.9 \%$ of Danish patients, with less pronounced predominance of women (11.8\% versus $9.4 \%$ in men) [16]. In USA, only $10 \%$ of dermatitis were facial [21].

Table 4. Most frequent etiologic agents of ACD in the literature.

\begin{tabular}{|c|c|c|c|}
\hline Authors & Year & Country & Most frequent etiologic agents \\
\hline Our study & $2002-2012$ & Tunisia & $\begin{array}{l}\text { Cement } \\
\text { Potassium Dichromate } \\
\text { Glues }\end{array}$ \\
\hline Lyons G et al. (19) & 2013 & Australia & $\begin{array}{c}\text { Formaldehyde } \\
\text { Fragrances } \\
\text { Rubber }\end{array}$ \\
\hline Bensefa-Colas L et al. (20) & 2001-2010 & France & $\begin{array}{l}\text { Metals } \\
\text { Hairdressing Products } \\
\text { Biocides }\end{array}$ \\
\hline Wang BJ et al. (21) & 2011 & Taiwan & $\begin{array}{c}\text { Potassium Dichromate } \\
\text { Thiuram Mix } \\
\text { Cobalt }\end{array}$ \\
\hline Macan J et al. (22) & 2013 & Croatia & $\begin{array}{c}\text { Metals } \\
\text { Thiuram Mix } \\
\text { Isopropyl-n-phenyl-p-phenylenediamine }\end{array}$ \\
\hline Schwensen JF et al. (23) & 2003-2012 & Denmark & $\begin{array}{l}\text { Potassium Dichromate } \\
\text { Epoxy Resin } \\
\text { 2-bromo-2-nitropropane-1,3-diol }\end{array}$ \\
\hline Reduta T et al. (24) & $2007-2011$ & Poland & $\begin{array}{l}\text { Nickel Sulfate } \\
\text { Cobalt } \\
\text { Fragrance Mix }\end{array}$ \\
\hline
\end{tabular}


Job loss rates were evaluated in few studies. A definitive work cessation was observed among $25.4 \%$ of our cases which was similar to the results of Malkonen $\mathrm{T}$ et al. who estimated the loss of employment among 605 Danish worker with occupational dermatitis at 25\% [22]. In Sweden, job loss was noted in 15\% of patients with occupational skin diseases [23]. Thus, social repercussions of ACD are considerable and a preventive strategy is indispensable in order to minimize these complications and ensure an adequate professional career [24].

This study has some limitations. Firstly, it is a retrospective study, therefore certain information may be lacking. Secondly, enrolled patients were those declared with an occupational ACD and recognized by the National Health Insurance Fund. Recognition of occupational diseases is not only based on medical diagnosis but also on legal restrictions. Thus, authentic occupational ACD could be rejected because of non-compliance with statutory deadlines and lead to an underestimation of incidence and prevalence of the disease. Also, this cohort may have the bias of including only very severe cases which were referred to the Health Insurance System. However, it is the first national study that estimates the epidemiology of this occupational disease and provides an estimation of its incidence. Also, data collected from official authorities still reliable and valid.

\section{Conclusion}

The annual incidence of occupational ACD is 31.65 cases/100.000 workers in the private sector in Tunisia. ACD is more frequent among men but the most represented sector was textile and clothing. Metals are the most common allergens in Tunisia. A quarter of patients lost their jobs due to their skin disease. Occupational allergic contact dermatitis is still responsible for considerable professional and social handicaps requiring rigorous observance of preventive measures in order to reduce these repercussions.

\section{Conflict of Interest}

No conflict of interest was declared by the authors.

\section{Financial Disclosure}

The authors declared that this study received no financial support.

\section{References}

[1] Cashman, M.W., Reutemann, P.A. and Ehrlich, A. (2012) Contact Dermatitis in the United States: Epidemiology, Economy Impact and Workplace Prevention. School of Medicine and Health Sciences, George Washington University, Washington DC, 87-98.

[2] Azaiez A. (2013) Statistiques des accidents de travail et des maladies professionnelles. Revue Tunisienne de pathologie professionnelle de Penvironnement, 2, 86-91.

[3] Farage, M.A., Katsarou, A. and Maibach, H. (2006) Sensory, Clinical and Physiological Factors in Sensitive Skin: A Review. Contact Dermatitis, 55, 1-14.

https://doi.org/10.1111/j.0105-1873.2006.00886.x 
[4] Kalish, R. and Askenase, P. (1999) Molecular Mechanisms of CD8+ T Cell-Mediated Delayed Hypersensitivity: Implication of Allergies, Asthma and Autoimmunity. Journal of Allergy and Clinical Immunology, 103, 192-199. https://doi.org/10.1016/S0091-6749(99)70489-6

[5] Geraut, C. and Tripodi, D. (2001) Dermatoses Professionnelles. EMC Dermatologie.

[6] Cvetkovski, R., Zachariae, R., Jensen, H., Olsen, J., Johansen, J. and Egner, T. (2006) Prognosis of Occupational Hand Eczema: A Follow-Up Study. JAMA Dermatology, 142, 305-311. https://doi.org/10.1001/archderm.142.3.305

[7] Meding, B., Wrangsjo, K. and Jarvholm, B. (2005) Fifteen-Year Follow-Up of Hand Eczema: Persistence and Consequences. British Journal of Dermatology, 152, 975-980. https://doi.org/10.1111/j.1365-2133.2005.06494.x

[8] Frimat, P. and Fantoni-Quinton, S. (2010) Aspects médico-légaux des dermatoses professionnelles. Archives des maladies Professionnelles et de Penvironnement, 71, 404-406.

[9] Athavale, P., Shumk, W. and Chen, Y. (2007) Occupational Dermatitis Related to Chromium and Cobalt: Experience of Dermatologist (EPIDERM) and Occupational Phisicinans (OPRAH) in U.K. over 11 Year Period (1993-2004). British Journal of Dermatology, 157, 518-22. https://doi.org/10.1111/j.1365-2133.2007.08030.x

[10] Donald, V. and Belsito, M.D. (2005) Occupationl Contact Dermatitis: Etiology, Prevalence and Resultant Impairement/Disability. Journal of the American Academy of Dermatology, 53, 303-313. https://doi.org/10.1016/j.jaad.2005.02.045

[11] Bordel-Gomez, M.T., Miranda-Romero, A. and Castrodeza-Sanz, J. (2010) Epidemiology of Contact Dermatitis: Prevalence of Sensitization to Different Allergens and Associated Factors. Actas Dermo-Sifiliográficas, 101, 59-75.

https://doi.org/10.1016/j.ad.2009.07.003

[12] Crépy, M.-N., Nosbaum, A. and Bensefa-Colas, L. (2013) Dermatoses Professionnelles. EMC Pathologie professionnelle et de Penvironnement, 8, 1-23.

[13] Zorba, E., Karpouzis, A., Zorbas, A., Bazas, T., Alexopouloset, E., et al. (2013) Occupational Dermatoses by Type of Work. Greece Safety and Health at Work, 4, 142-148. https://doi.org/10.1016/j.shaw.2013.06.001

[14] Ahn, Y.-S. and Kim, M.-G. (2010) Occupational Skin Diseases in Korea. Occupational and Environmental Medicine, 25, 46-52. https://doi.org/10.3346/jkms.2010.25.S.S46

[15] Gan, W.H., Low, R. and Koh, D. (2013) Dermatological Conditions in Military Conscripts. Occupational Medicine, 63, 435-438. https://doi.org/10.1093/occmed/kqt077

[16] Schwensen, J.F., Friis, U.F. and Menne, T. (2013) One Thousand Cases of Severe Occupational Contact Dermatitis. Contact Dermatitis, 68, 259-268. https://doi.org/10.1111/cod.12045

[17] Kopferschmitt-Kubler, M.C., Popin, E., Vervloet, D., Ameille, J. and Pauli, G. (2003) L'observation nationale des asthmes professionnels. The National Occupational Asthma Registry. Revue française d allergologie et dimmunologie clinique, 43, 6-12. https://doi.org/10.1016/S0335-7457(02)00011-4

[18] Agence de promotion de l'industrie et l'innovation (2010) Les industries diverses en Tunisie: Monographie. Ministère de l'industrie et de la technologie. http://www.tunisieindustrie.nat.tn

[19] Raison-Peyron, N. (2006) Le diagnostic des eczémas professionnels. Revue Française $d$ allergologie et d immunologie clinique, 46, 45-50. 
https://doi.org/10.1016/S0335-7457(06)80028-6

[20] Zouhaier, K., El Jazouly, M., Berrada, R., et al. (2007) Eczémas de contact du visage aux cosmétiques. Annales de Dermatologie et de Venerologie, 134, 53.

https://doi.org/10.1016/S0151-9638(07)89080-6

[21] Belsito, D.V. (2005) Ocuupational Contact Dermatitis: Etiology, Prevalence and Resultant Impairement/Disability. Journal of the American Academy of Dermatology, 53, 303-313.

[22] Malkonen, T., Alanko, K., Jolanki, R., Luukkonen, R., Aalto-Korte, K., Lauerma, A. and Susitaival, P. (2010) Long-Term Follow-Up Study of Occupational Hand Eczema. British Journal of Dermatology, 163, 999-1006. https://doi.org/10.1111/j.1365-2133.2010.09987.x

[23] Cvetkovski, R.S., Rothman, K.J., Olsen, J., Mathiesen, B., Iversen, L., Johansen, J.D. and Agner, T. (2005) Relation between Diagnoses on Severity, Sick Leave and Loss of Job among Patients with Occupational Hand Eczema. British Journal of Dermatology, 152, 93-98. https://doi.org/10.1111/j.1365-2133.2005.06415.x

[24] Crépy, M.N. (2012) Dermatoses professionnelles, actualités 2012. Revue française d allergologie, 52, 212-217. https://doi.org/10.1016/j.reval.2012.01.011 